Am. J. Trop. Med. Hyg., 64(3, 4), 2001, pp. 194-203

Copyright $(\mathcal{C} 2001$ by The American Society of Tropical Medicine and Hygiene

\title{
IDENTIFICATION OF FREQUENTLY RECOGNIZED DIMORPHIC T-CELL EPITOPES IN PLASMODIUM FALCIPARUM MEROZOITE SURFACE PROTEIN-1 IN WEST AND EAST AFRICANS: LACK OF CORRELATION OF IMMUNE RECOGNITION AND ALLELIC PREVALENCE
}

\author{
EDWIN A. M. LEE, KATIE L. FLANAGAN, KENNEDY ODHIAMBO, WILLIAM H. H. REECE, COLIN POTTER, \\ ROBIN BAILEY, KEVIN MARSH, MARGARET PINDER, ADRIAN V. S. HILL, AND MAGDALENA PLEBANSKI \\ Molecular Immunology Group, Institute of Molecular Medicine, Nuffield Department of Medicine, University of Oxford, \\ John Radcliffe Hospital, Oxford, United Kingdom; Kenya Medical Research Institute, Kilifi Research Unit, Kilifi, Kenya; \\ London School of Hygiene and Tropical Medicine, Keppel Street, London, United Kingdom; \\ Medical Research Council Laboratories, Fajara, Banjul, The Gambia
}

\begin{abstract}
The merozoite surface protein-1 (MSP1) is the most studied malaria blood-stage vaccine candidate. Lymphokines such as interferon gamma (IFN- $\gamma$ ) and interleukin 4 (IL-4) may mediate blood-stage specific protection. Here we identify Plasmodium falciparum MSP1 T-cell epitopes capable of rapid induction of IFN- $\gamma$ and/or IL-4 from peripheral blood mononuclear cells of East and West African donors. Both allelic forms of these novel MSP1 T-cell epitopes were stimulatory. An unusually high numbers of Gambian responders $(>80 \%)$ to these epitopes were observed, suggesting that MSP1 reactivity may have been underestimated previously in this population. Surprisingly, IFN- $\gamma$ responses to allelic T-cell epitopes failed to correlate with differential antigenic exposure in The Gambia compared to Kenya. These results suggest an unexpected level of immunoregulation of IFN- $\gamma$ response with variable allelic T-cell reactivity independent of the level of antigenic exposure. Further analysis of the mechanisms determining this response pattern may be required if vaccines are to overcome this allelic reactivity bias in malaria-exposed populations.
\end{abstract}

\section{INTRODUCTION}

The success of an effective malaria blood-stage vaccine may depend on its ability to induce both cellular and humoral immunity. ${ }^{1}$ A major blood-stage vaccine candidate is the merozoite surface protein-1 (MSP1) of Plasmodium falciparum. $^{2}$ Antibodies to MSP1 can mediate murine, primate and human blood-stage immunity. ${ }^{3-8}$ The role of blood-stage specific human $\mathrm{T}$ cells is less clear, although some T-cell epitopes have been defined, ${ }^{9-15}$ and T-cell proliferative and interferon gamma (IFN- $\gamma$ ) responses may be associated with reduced susceptibility to clinical malaria. ${ }^{16,17}$ The full range of T-cell epitopes present in MSP1 is unknown.

It is unclear which cellular immune mechanisms protect against human blood-stage malaria. In Plasmodium chabaudi infection, T-helper 1 (Th1) followed by T-helper 2 (Th2) responses both contribute to protection. ${ }^{18-20}$ Naturally-exposed populations have IFN- $\gamma$ secreting MSP1 specific T cells, ${ }^{11,16,17}$ but it is unclear whether they may also have IL4 producing T cells. Previous attempts to measure IL- 4 production by ELISA may have been unsuccessful due to the low sensitivity of this assay. ${ }^{11}$ The enzyme-linked immunospot (ELISPOT) assay is 20- to 200-fold more sensitive than ELISA. $^{21,22}$ ELISPOT assays detect only circulating effector $\mathrm{T}$ cells capable of rapid (16-24 hr) lymphokine secretion, and thus do not rely on in vitro expansion of antigen specific $\mathrm{T}$ cells. Early T-cell lymphokine secretion may play a role in the subsequent Th1/Th2 bias of blood-stage immunity. Here Th1 and Th2 responses were assessed in ELISPOT assays of MSP1 peptides that differed between the MAD20 and WELLCOME types and were predicted to bind protective African HLA class II alleles. Novel T-cell epitopes were identified which were frequently recognized by malaria-exposed donors. A Th1 bias of responses was confirmed for the majority of these T-cell epitopes.

MSP1 is a dimorphic protein, represented by two allelic types, MAD20 and WELLCOME. ${ }^{23}$ Parasite epidemiological studies show different distributions of these allelic strains in West $^{24}$ compared to East Africa. ${ }^{25}$ It was therefore of interest to compare the allelic MSP1 T-cell reactivity patterns between West and East Africa. Whereas IL-4 responses to specific T-cell epitopes reflected the epidemiological parasite prevalence in The Gambia, IFN- $\gamma$ responses did not, either in The Gambia or Kenya, suggesting that IFN- $\gamma$ and IL-4 production were independently regulated. Moreover, these results suggest that immune selection may act on MSP1 through a selected T-cell effector activity. These findings have important implications for our understanding of hostparasite interactions and may be of direct relevance to the design of vaccines which aim to boost protective responses in malaria endemic populations.

\section{MATERIALS AND METHODS}

Study area and volunteers. Malaria-exposed adults were from the villages of Brefet, Jali, and Berending in The Gambia, West Africa and from the villages around Kilifi in Kenya, East Africa. These studies were approved by the Ethical Committee of The Gambia Medical Research Council and the Kenya Medical Research Institute. All adult subjects were aged between 18-60 years-old. Thick and thin blood films were prepared at the time of bleeding, stained with Giemsa, and examined by microscopy for the presence of circulating malaria parasites. All malaria-exposed donors were clinically healthy and parasite-negative by microscopy at the time of blood sampling.

High malaria transmission in The Gambia commences shortly after the start of the rainy season and occurs between August and November. ${ }^{26}$ Gambian samples were collected both before (March to April, 1998) and after the wet season (October to November, 1998). No statistical differences in Gambian IFN- $\gamma$ reactivity patterns between samples collect- 
ed during the wet and dry seasons were observed (data not shown). Malaria transmission in Kenya is highest during and following the long rains (March to May) with a second peak of transmission occurring after the short rains in October to December. ${ }^{27}$ Kenyan samples were taken after the wet season (July to August, 1999). Malaria-unexposed donors were used as negative controls for IFN- $\gamma$ and IL-4 ELISPOT detection assays. These were clinically healthy European-Caucasian volunteers aged between 21-50 years from Oxford, UK, who had not traveled to a malaria-endemic country.

Blood collection and cell preparations. After informed consent, $20 \mathrm{ml}$ of venous blood was collected into heparin. Cells were separated by density gradient centrifugation on Lymphoprep $^{\mathbb{W}}$ (Pharmacia, Oslo, Norway) at $800 \mathrm{~g}$ for 20 min. Peripheral blood mononuclear cells (PBMCs) were collected from the blood-ficoll interface and washed three times in RPMI-1640 medium (Sigma, Irvine, UK). PBMCs were resuspended at $4 \times 10^{6}$ per $\mathrm{ml}$ in RPMI-1640 medium supplemented with $5 \%$ heat inactivated human $\mathrm{AB}$ serum, 2 MM glutamine (Gibco, Paisley, UK), $100 \mu \mathrm{g}$ per ml streptomycin (Gibco) and 100 units per $\mathrm{ml}$ penicillin (Gibco) (RN5) prior to use in ELISPOT assays.

MSP1 peptides. HLA-DRB1*1302 (DR1302) and HLADRB1*1301 (DR1301) alleles are identical except for a glycine to valine change at position 86 of the HLA-DR $\beta$ chain which affects the preference for particular hydrophobic peptide residues. ${ }^{28}$ DR1302, but not DR1301, was shown to be protective against severe malaria in The Gambia. ${ }^{29}$ Hence, DR1302 and DR1301 alleles may present different peptides to CD4+ T cells. Thus, a "subtracted motif" which characterized peptides that could bind to the allelic motif of DR1302 but not to DR1301 was defined. By contrast in Kenya, HLA-DRB1*0101 (DR1) but not DR1302 or DR1301 was shown to be protective against severe malaria (Yates SN, unpublished data). Two selection criteria for choosing MSP1 peptides were employed: one based on the peptidebinding motifs of the two protective class II alleles, HLADRB1*0101 (DR1) and DR1302; the other based on this "subtracted motif." Using a computer prediction algorithm ${ }^{30}$ which predicted potential T-cell epitopes that differed between two major allelic types of MSP1, MAD20 and WELLCOME type, a total of 26 allelic variant peptides were synthesized (Table 1). This computer program utilizes pool sequence data from HLA class-II proteins and scans the MSP1 protein for candidate epitopes that fit the HLA class-II peptide motif. A probability of being processed and presented (PPP) algorithm score is assigned to each amino acid of the protein which determines the probability of a 15-mer peptide beginning with that amino acid to be naturally processed and presented. All peptides were purified by high-performance liquid chromatography (HPLC) and purity ranged from $>$ $80 \%$ to $>95 \%$. Peptides were reconstituted in sterile phosphate-buffered saline (PBS) and used at a pre-determined optimal culture concentration of $25 \mu \mathrm{g} / \mathrm{ml}$. When tested in pools each peptide was used at $25 \mu \mathrm{g} / \mathrm{ml}$. Table 1 shows the composition of the peptide pools. Peptides were grouped into non-overlapping pools of 2 or 3 peptides based on their allelic type (MAD20 or WELLCOME) and their peptide motif to either DR1 or DR1302.

Control antigens. The mitogen phytohemoglutin (PHA) (Wellcome Pharmaceuticals, Stevenage, UK) and two recall antigens, tetanus toxoid (TT) (Evans Biomedical, Horsham, UK), and purified protein derivative (PPD) from Mycobacterium bovis (Statens Serum Institut, Copenhagen, Denmark) were used as positive controls antigens. PHA was used at 1 $\mu \mathrm{g} / \mathrm{ml}$ and the two recall antigens were used in cultures at $10 \mu \mathrm{g} / \mathrm{ml}$.

Ex-vivo ELISPOT assays. Ninety-six well polyvinylidene difluroide (PVDF) backed plates (MAIP S45, Millipore, Molsheim, France) were coated with $15 \mu \mathrm{g} / \mathrm{ml}$ of monoclonal anti-human IFN- $\gamma(1-D 1 K)$, or IL-4 (IL-4-I), or IL-10 (9-D7) antibodies (all from Mabtech, Nacka, Sweden) for 3 hours at room temperature (RT) or overnight at $4^{\circ} \mathrm{C}$. The plates were then washed 5 times with sterile PBS pH 7.4, (Sigma) and then blocked for 1 hour at RT with RPMI-1640 supplemented with $10 \%$ heat inactivated human $\mathrm{AB}$ serum (RN10). PBMCs were plated at $100 \mu l\left(4 \times 10^{5}\right.$ cells $)$ per well. MSP1 peptides, peptide pools, or antigens were added to each well. The plates were incubated at $37^{\circ} \mathrm{C}$ in $5 \% \mathrm{CO}_{2} /$ $95 \%$ air (18 hr for IFN- $\gamma$ detection, $24 \mathrm{hr}$ for IL-4 and IL10 detection). Plates were then processed by washing 4 times in PBS with $0.05 \%$ Tween-20 (Sigma) and 2 times with PBS. One microgram per milliliter of the second biotinylated monoclonal antibody of either IFN- $\gamma$ (7-B6-1-Biotin), IL-4 (IL-4-II-Biotin) or IL-10 (12G8-Biotin) (all from Mabtech) was added and incubated for 2 hours at RT. The plates were washed as described above and incubated for 1 hour at RT with $1 \mu \mathrm{g} / \mathrm{ml}$ strepavidin alkaline phosphatase (ALP). These were washed again and developed with the ALP conjugate substrate kit (Biorad, Hercules, CA). Individual cytokineproducing cells within each well leave a "footprint" or spot which is visualized with the aid of a dissecting microscope (magnification $\times 2$ ). Data is presented as spot-forming-units (SFU) per million PBMC.

A response was considered positive if the probability of a cell forming a spot was higher in the test well compared to the negative-control well $(P<0.05)$. The significance test was a chi-squared comparison of the odds ratios of numbers of lymphokine-positive cells in the test well and the control well. ${ }^{31}$ This method of determining a significant positive ELISPOT response is as powerful as non-parametric or parametric comparisons of the means or medians of several replicate wells. The null hypothesis tested by our significance test is: the probability of a cell forming a spot in the control well is the same as the probability of a cell forming a spot in the well with peptide. The null hypothesis is rejected at the $95 \%$ confidence limit if there are at least $\geq 5$ spots in the test well than in the control well. This significant cut-off value above background spots higher than zero increased based on a binomial distribution assuming $4 \times 10^{5}$ cells per well. Similar significant values were obtained if a Poisson model was used.

Molecular detection of MSP1 allelic strain distribution. DNA samples of Gambian ${ }^{29}$ and Kenyan (Yates SN, unpublished data) children with clinical malaria were collected as part of an earlier case-control study of malaria. Part of the $P$. falciparum MSP1 gene (283 base pairs [bp]) corresponding to the allelic variant epitope pair, M3/M4 was amplified by polymerase chain reaction (PCR) with biotinylated primers $\left(5^{\prime}\right.$ to $\left.3^{\prime}\right)$ : TACAATAAACAATTACAAGAAGC and TTAAATAATATTCTAAT-TCAAGTGG. Polymerase chain reaction was carried out in $16 \mathrm{mM}\left(\mathrm{NH}_{4}\right)_{2} \mathrm{SO}_{4}, 67 \mathrm{mM}$ tris 




FIGURE 1. Percentage positive IFN- $\gamma$ lymphokine responders of 22 malaria-exposed donors reacting to the panel of MSP1 peptides. Peripheral blood mononuclear cells from adult Gambians were stimulated separately with either MSP1 allelic variant peptide (MAD20 or WELLCOME) in a $16 \mathrm{hr} e x$-vivo IFN- $\gamma$ release assay. Positive IFN- $\gamma$ enzyme-linked immunospots (ELISPOTs) detect a precursor frequency of $>1$ per $1 \times 10^{5}$ responding cells $(P<0.05)$. The MSP1 protein is divided into 17 blocks based on amino-acid homology between dimorphic types. ${ }^{23}$ Conserved ( $\square$ ), semi-conserved (shaded $[\square]$ ) and polymorphic $(\square)$ blocks are shown. Untested MSP1 allelic variant peptides are represented by an asterisk.

$\mathrm{HCl}(\mathrm{pH} 8.8), 0.01 \%$ Tween $20,0.5 \mathrm{mM} \mathrm{MgCl}_{2}$, and 0.5 $\mathrm{mM}$ spermidine, with deoxynucleotide triphosphates $(0.2$ $\mathrm{mM}$ ) and a $0.5 \mathrm{mM}$ concentration of each primer, for an initial denaturation step of $94^{\circ} \mathrm{C}$ for $1,080 \mathrm{sec}$, followed by 32 cycles each of $10 \mathrm{sec}$ at $94^{\circ} \mathrm{C}, 30 \mathrm{sec}$ at $48^{\circ} \mathrm{C}$, and $60 \mathrm{sec}$ at $72^{\circ} \mathrm{C}$. To obtain single stranded PCR products, $5 \mu \mathrm{l}$ of PCR product was denatured in equal volume of $1.6 \%$ sodium hydroxide solution for $5 \mathrm{~min}$ at room temperature. The denatured samples were then transferred to a pre-washed strepavidin coated microtitration plates (Wallac Oy, Turku, Finland).

The molecular detection of M3/M4 allelic types was by allele-specific hybridization of Europium (Eu) labeled M3 (MAD20) or Samarium (Sm) labeled M4 specific probe to single-stranded PCR products immobilized on pre-washed strepavidin-coated microtitration plates (Wallac Oy). To obtain single-stranded PCR products, $5 \mu \mathrm{l}$ of PCR product was denatured by an equal volume of $1.6 \%$ sodium hydroxide solution for $5 \mathrm{~min}$ at room temperature and added to $100 \mu \mathrm{l}$ of DELFIA assay buffer (Wallac Oy), containing $2 \mathrm{ng}$ Eulabeled M3 (MAD20) specific probe $\left(5^{\prime}\right.$ to $\left.3^{\prime}\right)$, Eu-GAAGATATAGATAAA and $5 \mathrm{ng}$ Sm-labeled M4 (WELLCOME) specific probe (5' to $\left.3^{\prime}\right)$, Sm-GATAAGATAAATGAA per well. Plates were incubated for $1 \mathrm{hr}$ at room temperature on a plate shaker and washed 6 times in Wallac wash solution to remove excess unbound probes. $200 \mu l$ of
Wallac enhancement solution was added per well to activate the fluorescence labeled probes and the plates were shaken for a further $45 \mathrm{~min}$ at room temperature. Fluorescent signals from simultaneously hybridized Eu- and Sm-labeled specific probes were then measured and quantified using a time-resolved 1234 Wallac Fluorometer. The number of samples that hybridized to Eu (MAD20) or Sm (WELLCOME) probes was expressed as a percentage of the total number of Gambian (234 total) and Kenyan (212 total) samples. Similar results were obtained typing the same Gambian donors by standard dot-blot hybridization with allele-specific oligonucleotide probes $^{32}$ (data not shown).

\section{RESULTS}

Peripheral-blood mononuclear cells from 22 malaria-exposed Gambian adults were tested in IFN- $\gamma$ ELISPOT responses to MSP1 peptides (Figure 1). Table 1 lists the peptides, selected on the basis of sequence differences between MAD20 and WELLCOME types and predicted binding to protective African HLA class II alleles HLA-DRB1*1302 (DR1302) and HLA-DRB1*0101 (DR1). ${ }^{29}$ The majority (18 of 22) of individuals gave an IFN- $\gamma$ response to at least one MSP1 peptide. A minimum of four individuals responded to each of these MSP1 peptides. This unexpectedly high level of reactivity was unlikely to be due to stimulation of naive 
TABLE 1

Panel of MSP1 allelic variant (MAD20, top, and WELLCOME, bottom) peptide pairs used in malaria-exposed donors in West and East Africa Peptides were grouped into nonoverlapping peptide pools, P1 to P8. Peptide pools P1 to P4 correspond to the MAD20 allele, whereas P5 to P8 correspond to the WELLCOME allele. Amino acid positions are taken from Miller and others. ${ }^{56}$ MSP1 MAD20 peptides with the DR1 motif were in P1 and P2, and WELLCOME peptides with DR1 motifs were in P5 and P6. MAD20 peptides with the DR1302 motif were in P3 and P4, and WELLCOME peptides with DR1302 motifs were in P7 and P8 (M37, M34). Peptides M3 through M8 were tested individually both in The Gambia and Kenya

\begin{tabular}{|c|c|c|c|}
\hline No. & Position & Sequences & Peptide pools \\
\hline \multicolumn{4}{|c|}{ MAD20 } \\
\hline M3 & $344-357$ & N E N I K K L L E D I D K I & \\
\hline M5 & $310-328$ & L Y Q A Q Y N L F I Y N K Q L Q E A H & \\
\hline M7 & $1538-1550$ & D Y L I N L K A K I N D C & \\
\hline M19 & $268-282$ & K M E D Y I K K N K T T I A N & $\mathrm{P} 1$ \\
\hline M21 & $471-485$ & N P D T K E K I N E K I I T D & $\mathrm{P} 1$ \\
\hline M23 & $524-538$ & S K K D Y E E L L E K F Y E M & $\mathrm{P} 2$ \\
\hline M25 & $698-712$ & K P E P Y Y L I V L K K E V D & $\mathrm{P} 2$ \\
\hline M28 & $1429-1443$ & I I E D S F K L L N S E Q K N & \\
\hline M30 & $1465-1479$ & E G I S Y Y E K V L A K Y K D & \\
\hline M32 & $444-457$ & I V Y P L P L T D I H N S L & P3 \\
\hline M36 & $1185-1199$ & D N Y A N L E K F R A L S K I & P3 \\
\hline M38 & $464-477$ & N S Y G D L M P D T K E K & $\mathrm{P} 4$ \\
\hline M41 & $519-532$ & E D Y E K S K K D Y E E L L & $\mathrm{P} 4$ \\
\hline \multicolumn{4}{|c|}{ WELLCOME } \\
\hline M4 & $344-357$ & N E N I K E L L D K I N E I & \\
\hline M6 & $310-328$ & L Y Q A Q Y D L S I Y K Q L E E A H & \\
\hline M8 & $1538-1550$ & L F V I H L E A K V L N V & \\
\hline M20 & $268-282$ & K M E D Y I K K N K K T I E N & \\
\hline M22 & $471-485$ & N P F D Y T K E P S K N I Y T & P5 \\
\hline M24 & $524-538$ & I T K E Y E K L L N E I Y D S & P5 \\
\hline M27 & $698-712$ & K Q E P Y Y L I V L K K E I D & P6 \\
\hline M29 & $1429-1443$ & V V K D P Y K F L N K E K R D & P6 \\
\hline M31 & $1465-1479$ & D V L G Y Y K I L S E K Y K S & P6 \\
\hline M34 & $444-457$ & V T Y P L S Y N D I N N A L & P7 \\
\hline M37 & $1185-1199$ & D N Y A S L E N F K V L S K L & P7 \\
\hline M39 & $464-477$ & N S F G D L I N P F D Y T K & P8 \\
\hline M42 & $519-532$ & K S L N D I T K E Y E K L L & P8 \\
\hline
\end{tabular}

$\mathrm{T}$ cells, since malaria-naive donors $(\mathrm{n}=25)$ did not have IFN- $\gamma$ reactivity to these MSP1 peptides (data not shown). IFN- $\gamma \mathrm{T}$ cell responses in Gambian donors were found distributed throughout the MSP1 protein, with no immunodominant regions (Figure 1).

MSP1 is a dimorphic protein with allelic types designated MAD20 and WELLCOME. ${ }^{23}$ Seroepidemiological studies in The Gambia have shown a stable parasite distribution over time with MAD20 at 95\% and WELLCOME at 5\%. ${ }^{16,24,33}$ However, the MSP1 dimorphic epitopes identified here were recognized overall to a similar degree in Gambian donors; MAD20 responses: $36.8 \% \pm 2.6$ standard error (SE), WELLCOME responses: $28.4 \% \pm 4.6 \mathrm{SE}$. This reactivity pattern was surprising given the marked excess of the MAD20 allele (95\%) in The Gambia. ${ }^{24}$ Molecular typing of MSP1 allelic strain distribution using the sequence-encoding variant peptides M3 and M4 in block 3 of the gene in > 200 Gambians with clinical malaria confirmed the high prevalence of MAD20 (MAD20: 88\%, WELLCOME: 12\%). Heterogeneity was observed in the prevalence of IFN $\gamma$ responses to MAD20 or WELLCOME for different MSP1 allelic T-cell epitope pairs. Thus, in the M5/M6 region, IFN$\gamma$ responses to the abundant MAD20 parasite form were prevalent (MAD20: 65\% versus WELLCOME: 35\%), whereas the adjacent allelic pair M3/M4 showed equal reactivity to both forms. Surprisingly, the allelic pair M7/M8 showed higher prevalence of responses to the rare WELL-
COME strain represented by M8 (M7: 25\% versus M8: 75\%). All epitopes selected on the basis of peptide motifs to DR1 (e.g., M3/M4), DR1302 (e.g., M5/M6) or the "subtracted motif", (e.g., M7/M8) could bind to varying degrees to DR1, DR7, DR1301, DR1302, and DR1501 in peptide binding assays (data not shown). Thus, these unusual allelic reactivity patterns were unlikely to be due to lack of binding to HLA-DR.

It was possible that T-cell responses to the MAD20 epitope variant were underestimated by assessing only IFN- $\gamma$, a characteristic Th1 lymphokine. Therefore, the allelic pairs of M3/M4, M5/M6, and M7/M8 were used to assess in parallel both early IFN- $\gamma$ and IL-4 production in a further 14 malaria-exposed adults in The Gambia (Figure 2 and Table 2). In general, fewer donors produced IL-4 (6 of 14 individuals) to these MSP1 epitopes compared to IFN- $\gamma$ (12 of 14 individuals). Malaria-naive donors $(\mathrm{n}=10)$ tested in similar IL-4 ELISPOT assays did not react to these allelic peptide pairs (data not shown). Individual donors could respond to different MSP1 epitopes either by IL-4 or IFN- $\gamma$. Thus, T cell release of IL-4 did not preclude the ability of a donor to respond by IFN- $\gamma$ (Figure 2). Indeed, 58\% (7 of 12 positive) of total IL-4 responses also had IFN- $\gamma$ responses to the same epitopes. Analysis of IFN- $\gamma$ and IL- 4 reactivity in all Gambian donors showed an average higher IFN- $\gamma$ (49\%) reactivity to MSP1 allelic variant epitopes compared to IL4 (14\%) (t-test, $P<2 \times 10^{-5}$ ) (Table 2$)$. 


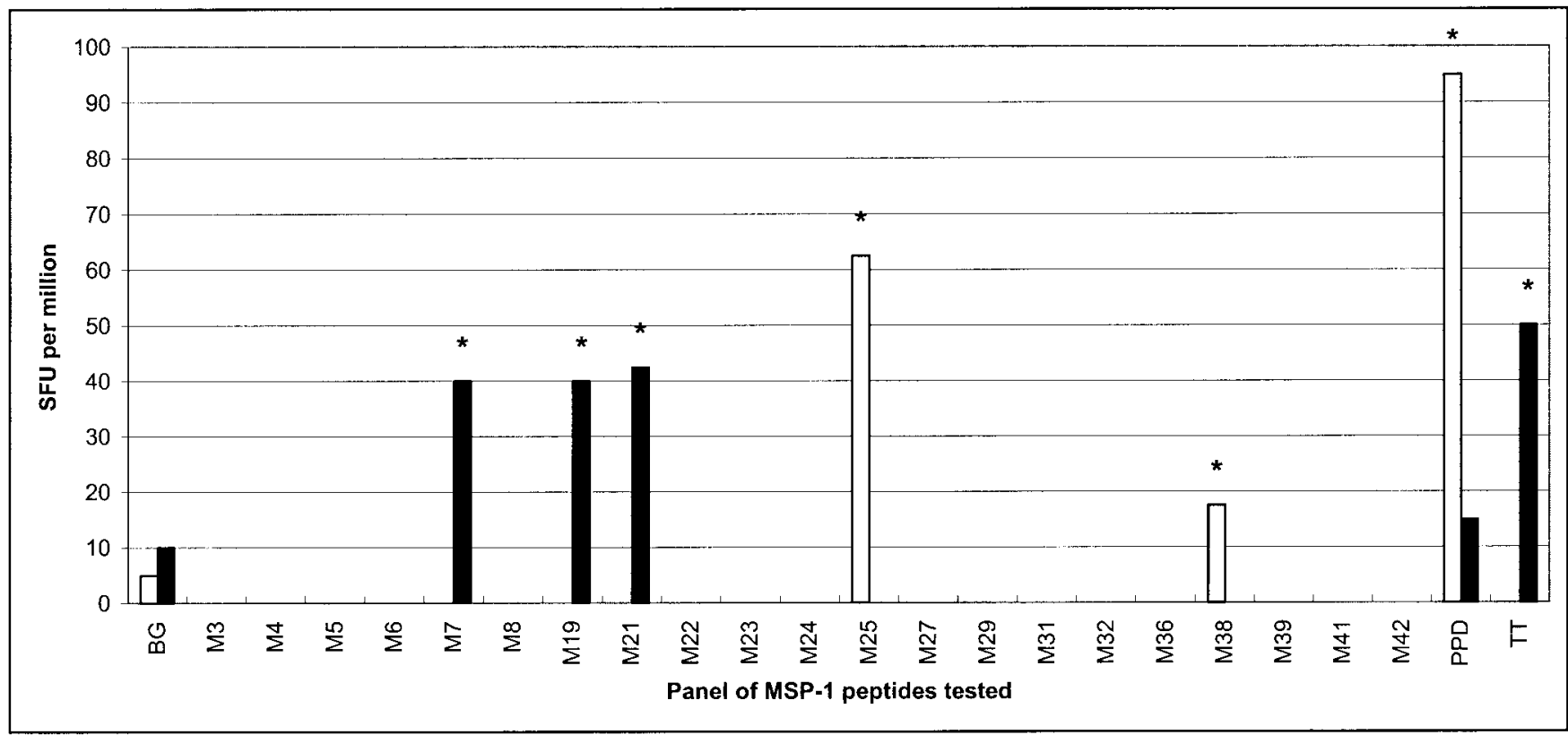

FIGURE 2. Influence of MSP1 allelic variants on ex-vivo IFN- $\gamma$ responses in a malaria-exposed donor in The Gambia. Peripheral blood mononuclear cells (PBMC) of a malaria-exposed donor, Donor Gam01 were tested in parallel ex-vivo IFN- $\gamma$ and IL-4 enzyme-linked immunospot (ELISPOT) assay to the panel of MSP1 peptides. Positive IFN- $\gamma(\square)$ and IL-4 (ם) producing T cells were represented as spot-forming units (SFU) per million PBMC. Purified protein derivative (PPD) and tetanus toxoid (TT) are respectively T-helper 1 (Th1) and T-helper 2 (Th2) positive control antigens. Significant $(P<0.05)$ lymphokine responses are marked with asterisks.

The analysis of the limited number of IL-4-specific responses detected suggested that they may reflect the MAD20 prevalence of parasites (Table 2). This contrasted with IFN$\gamma$ reactivity. Thus, IFN- $\gamma$ and IL-4 production to allelic-var-



iant epitopes may be independently regulated. However, total T-cell responsiveness (IFN- $\gamma$ and IL-4) still failed to reflect the higher MAD20 prevalence for allelic pairs M3/M4 and M7/M8.

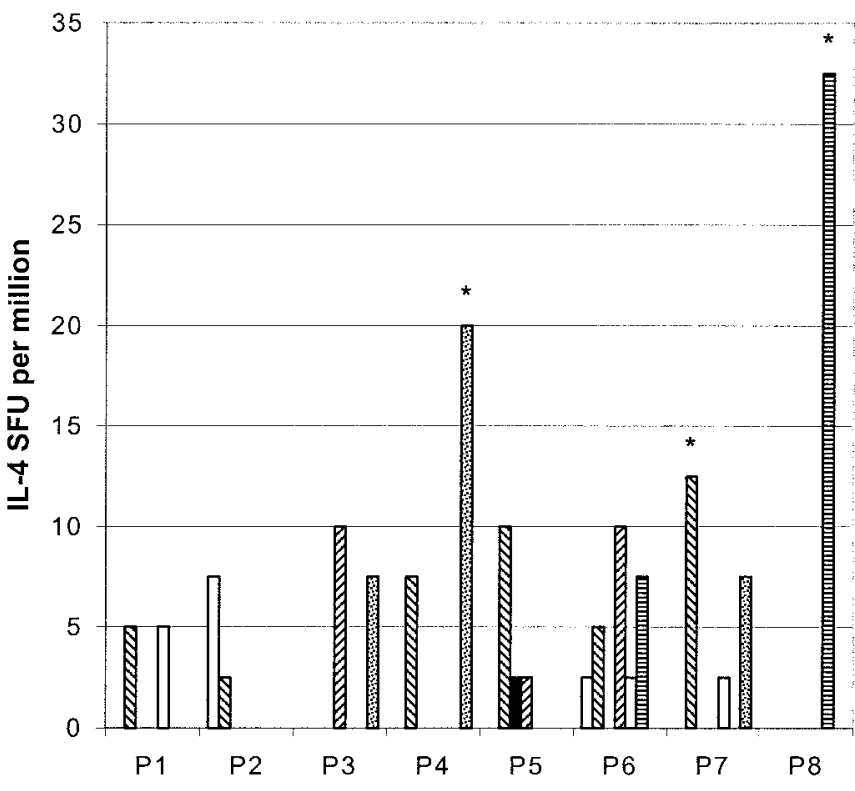

口Donor 1 Donor 2 Donor 3 Donor 4 Donor 5 目Donor 6 圈Donor 7

FIGURE 3A. Influence of MSP1 peptide pools and allelic variant peptide pairs in malaria-exposed donors in Kenya. Peripheral-blood mononuclear cells of 7 malaria-exposed Kenyan donors, Donors 1-7 were tested in parallel rapid IFN- $\gamma$ (left) and IL-4 (right) enzyme-linked immunospot (ELISPOT) assay to MSP1 peptide pools, P1 to P8 (See Table 1). Lymphokine responses were expressed as positive spot-forming units $(\mathrm{SFU})$ per million less the control SFU. Only significant $(P<0.05)$ responses were marked with an asterisk. 
TABLE 2

Summary of IFN- $\gamma$ and IL-4 positive responders to MSP1 allelic variant peptide pairs (M3/M4, M5/M6, and M7/M8) in malaria-exposed donors in The Gambia

\begin{tabular}{|c|c|c|}
\hline & IFN- $\gamma$ reactivity & IL-4 reactivity \\
\hline \multicolumn{3}{|l|}{ M3/M4 } \\
\hline $\begin{array}{l}\text { Peptide M3 } \\
\text { Peptide M4 } \\
\text { Specific (MAD20 versus WELLCOME) } \dagger \\
\text { Both variants } \ddagger\end{array}$ & $\begin{array}{l}20 / 45(44 \%) * \\
24 / 45(53 \%) * \\
17 \% \text { versus } 31 \% \\
52 \%\end{array}$ & $\begin{array}{l}3 / 14(21 \%)^{*} \\
2 / 14(14 \%)^{*} \\
50 \% \text { versus } 25 \% \\
25 \%\end{array}$ \\
\hline \multicolumn{3}{|l|}{ M5/M6 } \\
\hline $\begin{array}{l}\text { Peptide M5 } \\
\text { Peptide M6 } \\
\text { Specific (MAD20 versus WELLCOME) } \dagger \\
\text { Both variants } \ddagger\end{array}$ & $\begin{array}{l}24 / 40(60 \%)^{*} \\
19 / 40(48 \%)^{*} \\
30 \% \text { versus } 11 \% \\
59 \%\end{array}$ & $\begin{array}{c}2 / 14(14 \%)^{*} \\
0 / 14(0 \%)^{*} \\
100 \% \text { versus } 0 \% \\
0 \%\end{array}$ \\
\hline \multicolumn{3}{|l|}{ M7/M8 } \\
\hline $\begin{array}{l}\text { Peptide M7 } \\
\text { Peptide M8 } \\
\text { Specific (MAD20 versus WELLCOME) } \dagger \\
\text { Both variants } \ddagger\end{array}$ & $\begin{array}{l}16 / 44(36 \%) * \\
23 / 44(52 \%) * \\
9 \% \text { versus } 39 \% \\
52 \%\end{array}$ & $\begin{array}{l}3 / 14(21 \%)^{*} \\
2 / 14(14 \%)^{*} \\
33 \% \text { versus } 0 \% \\
67 \%\end{array}$ \\
\hline
\end{tabular}

It was interesting to speculate whether the high MSP1 reactivity and pattern of distribution of allelic variant specific immune responses were specific to The Gambia. A different pattern of reactivity might be expected in Kenya, since MSP1 allele frequencies in East Africa are different; equal frequencies of MAD20 and WELLCOME allelic types have been observed in Sudan. 25

MSP1 peptides (M19 to M42) were tested in pools of peptides (Table 1) in early IFN- $\gamma$ ELISPOT assays in 58
Kenyan malaria-exposed adults. Only limited IFN- $\gamma$ reactivity was observed in this population (Kenyan: MAD20 responses: $6.0 \% \pm 2.5 \mathrm{SE}$ and WELLCOME responses: $8.6 \%$ $\pm 2.8 \mathrm{SE}$ ) compared to Gambian reactivity to these epitopes (M19 to M42) (Gambian: MAD20 responses: 36.8\% \pm 1.7 SE and WELLCOME responses: $24.6 \% \pm 2.5 \mathrm{SE}$ ). Parasite typing of MSP1 strain distribution in $>200$ Kenyans with clinical malaria showed a significant (chi-square, $P<$ $\left.5 \times 10^{-8}\right)$ difference in distribution of MAD20 and WELL-
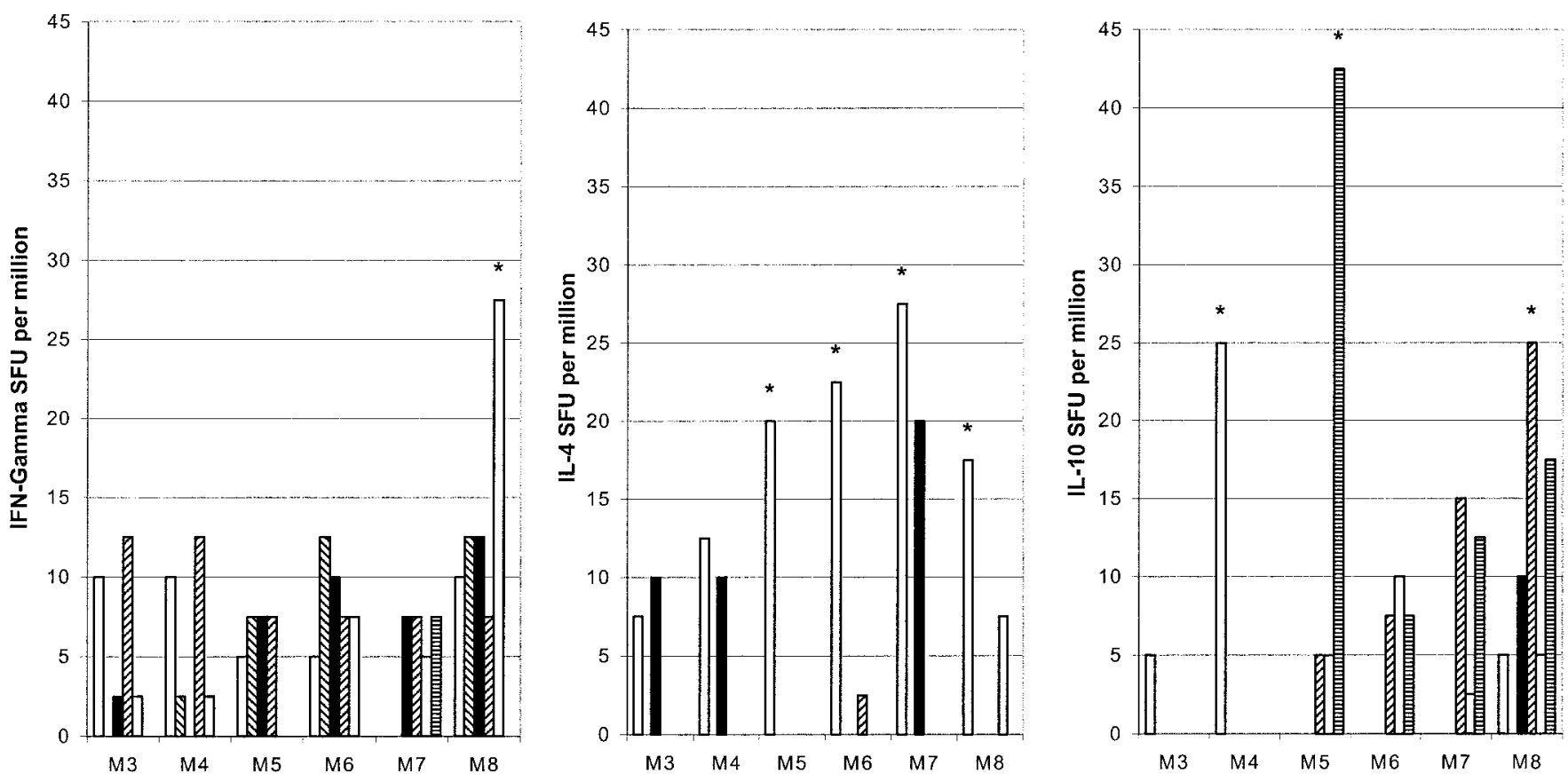

Donor 8 Donor 9

Donor 10

Donor 11

Donor 12

Donor 13

FIGURE 3B. Peripheral blood mononuclear cells of 6 malaria-exposed Kenyan donors, Donor 8-13 were tested in parallel ex-vivo IFN- $\gamma$ (left), IL-4 (middle) and IL-10 (right) ELISPOT assays to MSP1 allelic variant peptide pairs (MAD20/WELLCOME), M3/M4, M5/M6, and M7/M8. Lymphokine responses were expressed as positive SFU per million less the control SFU. Significant $(P<0.05)$ responses are marked with asterisks. 
TABLE 3

Summary of dry season IFN- $\gamma$ reactivity to MSP1 allelic variant peptide pairs (M3/M4, M5/M6 and M7/M8) in malaria-exposed donors in The Gambia and Kenya

\begin{tabular}{|c|c|c|}
\hline & Gambia reactivity & Kenya reactivity \\
\hline \multicolumn{3}{|l|}{ M3/M4 } \\
\hline $\begin{array}{l}\text { Peptide M3 } \\
\text { Peptide M4 } \\
\text { Specific (MAD20 versus WELLCOME) } \dagger \\
\text { Both variants } \$\end{array}$ & $\begin{array}{l}10 / 20(50 \%)^{*} \\
10 / 20(50 \%)^{*} \\
9 \% \text { versus } 18 \% \\
73 \%\end{array}$ & $\begin{array}{l}3 / 30(10 \%)^{*} \\
2 / 30(7 \%)^{*} \\
33 \% \text { versus } 0 \% \\
67 \%\end{array}$ \\
\hline \multicolumn{3}{|l|}{ M5/M6 } \\
\hline $\begin{array}{l}\text { Peptide M5 } \\
\text { Peptide M6 } \\
\text { Specific (MAD20 versus WELLCOME) } \dagger \\
\text { Both variants } \ddagger\end{array}$ & $\begin{array}{l}10 / 19(53 \%)^{*} \\
6 / 19(48 \%)^{*} \\
40 \% \text { versus } 0 \% \\
60 \%\end{array}$ & $\begin{array}{l}1 / 31(3 \%)^{*} \\
3 / 31(10 \%)^{*} \\
0 \% \text { versus } 67 \% \\
33 \%\end{array}$ \\
\hline \multicolumn{3}{|l|}{ M7/M8 } \\
\hline $\begin{array}{l}\text { Peptide M7 } \\
\text { Peptide M8 } \\
\text { Specific (MAD20 versus WELLCOME) } \dagger \\
\text { Both variants } \$\end{array}$ & $\begin{array}{c}4 / 19(21 \%)^{*} \\
11 / 19(57 \%)^{*} \\
0 \% \text { versus } 64 \% \\
36 \%\end{array}$ & $\begin{array}{c}1 / 31(3 \%)^{*} \\
4 / 31(13 \%)^{*} \\
0 \% \text { versus } 75 \% \\
25 \%\end{array}$ \\
\hline
\end{tabular}

COME in Kenya compared to The Gambia. The general pattern of T-cell reactivity in Kenyan donors (Table 3, Figure 3) reflected the local parasite strain distribution (MAD20: 68\%, WELLCOME: $32 \%$ ).

T-cell responses to MSP1 in East Africa may be Th2 mediated with concomitant down-regulation of IFN- $\gamma$ responses. To address this possibility, the peptide pools were tested for early IFN- $\gamma$ and IL-4 secretion in parallel in another seven exposed Kenyan donors. Figure 3A shows that few IL-4 responses were observed. In another six Kenyan donors tested for early Th1 (IFN- $\gamma$ ) and Th2 (IL-4 and IL-10) production assays to M3, M4, M5, M6, M7, and M8, no increase in Th2 responses over Th1 responses by assessing either lymphokine was observed in Kenya compared to The Gambia (Figure 3B). Therefore, the lower MSP1 reactivity in Kenya assessed by IFN- $\gamma$ release was unlikely to be due to cross-regulation by $\mathrm{Th} 2$ responses to these epitopes.

In The Gambia, the allelic IFN- $\gamma$ T-cell responses to the three variant pairs either followed (M5/M6) or failed to reflect (M3/M4, M7/M8) parasite prevalence. Whether differences in MSP1 parasite distribution could affect T-cell allelic reactivity patterns were characterized in thirty Kenyan malaria-exposed individuals (Table 3 ). In general, there was a lower IFN- $\gamma$ responder rate to these allelic pairs in Kenya than in The Gambia (paired t-test, $P<1 \times 10^{-3}$ ) (Table 3). Moreover, in Kenya, allelic pair M3/M4 gave slightly higher reactivity to MAD20 (M3:60\% versus M4:40\%). In contrast, both allelic pairs of M5/M6 and M7/M8 gave higher reactivity to the WELLCOME allelic type (M5:25\% versus M6: 75\%, M7:20\% versus M8:80\%). Thus, similar to data in The Gambia, there was a heterogeneity in the prevalence of MAD20 or WELLCOME responses in the three allelic variant epitopes, with only some epitope-specific responses following East African parasite prevalence.

Similar broad reactivity (responses to both allelic forms) patterns to the allelic pairs M3/M4, M5/6, and M7/8 in The Gambia and Kenya were observed (Table 3). However, a discordance between allelic specific responses and MSP1 parasite strain distribution was observed. Thus, only variant specific responses to M5/M6 reflected the epidemiological distribution of MSP1 alleles in both West and East Africa with a prevalence of M5 (MAD20) responses in The Gambia and higher M6 (WELLCOME) responses in Kenya. In contrast, allelic pair M3/M4 gave higher specific responses to M4 (WELLCOME) in The Gambia and a higher response to M3 (MAD20) in Kenya, in contrast to the expected epidemiological data. Surprisingly, the allelic pair M7/M8 had higher specific responses to the WELLCOME allele in both The Gambia and Kenya, independent of geographical differences in MSP1 allelic distribution. Thus, in this analysis of MSP1 allelic responses in two different populations in distinct geographical areas, IFN- $\gamma$ effector T-cell function to certain allelic T-cell epitopes failed to reflect MSP1 epidemiological distribution.

\section{DISCUSSION}

T-cell production of IFN- $\gamma$ has been implicated in protective immunity to blood-stage malaria. ${ }^{11,16,17}$ IFN- $\gamma$ can activate non-lymphocytic effector cells such as monocytes ${ }^{34,35}$ to control parasite growth through phagocytosis, ${ }^{36}$ generate reactive oxygen intermediates ${ }^{37}$ or L-arginine-derived nitric oxide. ${ }^{38,39}$ However, IFN- $\gamma$ does not control parasite growth by direct elimination of intra-erythrocytic parasites. ${ }^{40-42}$ In the present study, frequently recognized T-cell epitopes of MSP1 distributed throughout the protein were identified in naturally exposed malaria adults in The Gambia. The level of IFN- $\gamma$ reactivity ( $>80 \%$ ) to MSP1 epitopes was considerably higher than in previous proliferative studies of this antigen (range $30 \%$ to $40 \%$ ) in naturally exposed West African donors. ${ }^{11,16,17}$ This level of immune reactivity was independent of blood-sampling between dry and wet seasons (data not shown). The use of selected peptides with high binding potential to protective African alleles, or the detection of $\mathrm{T}$ cells with a different phenotype, i.e., rapid IFN- $\gamma$ production, may explain this higher level of reactivity. Interestingly, IFN- $\gamma$ T cell reactivity to MSP1 $(>80 \%)$ was higher than to the liver-stage antigens circumsporozite (CS) 
protein $(20 \%)$ and thrombospondin-related anonymous protein (TRAP) $(30 \%)$ tested in the same population (Flanagan $\mathrm{KL}$ and others, unpublished data). It remains to be determined whether this represents a general difference in response rate between blood-stage and pre-erythrocytic antigens. Since cells from individuals not exposed to malaria did not produce significant amounts of IFN- $\gamma$, it can be inferred that malaria exposure was required to observe this reactivity.

The extensive IFN- $\gamma$ reactivity to these epitopes in The Gambia supports the view that MSP1 is a major blood-stage antigenic target which may play a significant role in IFN- $\gamma$ mediated protection in vivo. In murine studies, IFN- $\gamma$ secreting $\mathrm{T}$ cell clones have been shown to be protect against malaria by a nitric-oxide dependent mechanism ${ }^{43}$ which may be dependent on macrophages and neutrophils. ${ }^{36,37}$ Alternatively, T-cell secretion of IFN- $\gamma$ may help in the induction of protective cytophilic MSP1 IgG blood-stage specific antibodies $^{44}$ and may assist in antibody-dependent cellular inhibitory mediated mechanisms. ${ }^{45}$ In recent prospective casecontrol studies of African children, IFN- $\gamma$ responses to merozoite antigens were associated with resistance to malaria reinfection..$^{46}$

T-cell reactivity in the $P$. falciparum pre-erythrocytic antigen, the circumsporozoite (CS) protein is focused on two immunodominant epitope regions at its highly polymorphic carboxyl terminus. ${ }^{47}$ No previous study has characterized immunodominance in the MSP1 protein. Such efforts may help in the identification of potential polymorphic regions under selection immune pressures. ${ }^{48,49}$ Recently, such polymorphic epitopes in the CS protein have been shown to mutually inhibit both T-cell priming ${ }^{50}$ and effector responses. ${ }^{32,51}$ Such regions could be excluded from future blood-stage vaccines. Here, MSP1 epitopes were distributed along the entire protein with no immunodominant regions. This suggests that multiple fragments of the MSP1 protein, both shed before and during RBC invasion ${ }^{52}$ can be processed and presented to induce effector $\mathrm{T}$ cells.

It was surprising to observe overall lower levels of MSP1 reactivity in Kenya $(27 \%, 8$ of 31 positive IFN- $\gamma$ responders) than The Gambia $(>80 \%)$, given the higher malaria transmission rate in the former. ${ }^{27}$ It could be argued that immunosuppression due to malaria parasitemia may be responsible. ${ }^{53}$ However, this was unlikely since (i) all Kenyan adults were negative for malaria parasites and (ii) statistical analysis of Gambian IFN- $\gamma$ reactivity patterns showed no difference between samples collected during the wet and dry seasons (data not shown).

It could be that low levels of reactivity to MSP1 simply reflect low rates of IFN- $\gamma$ responsiveness in East Africa compared to West Africa. However, T cell reactivity to the $P$. falciparum pre-erythrocytic antigens, CS protein and TRAP, showed a similar response rate (30\% in both locations) and a doubling of IFN- $\gamma$ responses in Kenya (60\%) compared to The Gambia (30\%), respectively (Flanagan KL and Plebanski $\mathrm{M}$, unpublished data). The same reagents and peptide batches were utilized when testing donors from The Gambia or Kenya, or control malaria-unexposed donors in Oxford. Since the testing of IFN $\gamma$ responses to CS protein, TRAP, and MSP1 responses was performed using the same assay and on the same donors both in The Gambia and Kenya, the lower reactivity to MSP1 in Kenya cannot be due to a general suppression of IFN $\gamma$ responses or assay differences. Interestingly, the general pattern of IFN- $\gamma$ allelic T-cell reactivity to MSP1 in 58 Kenyan adults was consistent with MSP1 parasite strain distribution in East Africa. By contrast, MSP1 peptide specific IFN- $\gamma$ responses in The Gambia did not show the expected excess of MAD20 over WELLCOME reactivity. ${ }^{24}$ Therefore, MSP1 immune reactivity in The Gambia may be regulated independently of antigenic exposure.

Malaria-exposed donors could respond to different MSP1 epitopes either by IFN- $\gamma$ or IL- 4 release. Thus, IL-4 T-cell production did not prevent IFN- $\gamma$ release to other epitopes and $58 \%$ of positive IL-4 responses also had IFN- $\gamma$ responses to the same epitopes, suggesting a Th1/Th- 0 profile. Independent IFN- $\gamma$ or IL-4 production to different MSP1 epitopes was also observed in Kenya where responses were either Th1 or Th2 specific. Interestingly, there was a separation of Th2 responses into either IL- 4 or IL-10 producing epitopes. Thus, MSP1 epitopes can induce independent Tcell production of Th1 or Th2 lymphokines. This independent immune regulation of IFN- $\gamma$ and IL-4 responses was also reflected in the distribution of allele-specific T-cell responses to dimorphic epitopes. IL-4 responses in Kenyan donors, although found less frequently than IFN- $\gamma$ in The Gambia, did follow the expected MAD20 prevalence.

It is not clear whether dimorphism in the MSP1 protein enables the parasite to evade variant-specific acquired immune responses. If this was the case, then such dimorphic epitopes might indeed have levels of immune responses that are not reflective of MSP1 parasite strain prevalence. Characterization of allele specific IFN- $\gamma$ responses to allelic MSP1 T-cell epitopes suggests that mechanisms other than parasite strain frequency-dependent immune selection ${ }^{54}$ may influence reactivity patterns. We speculate that immune evasion focused on IFN- $\gamma$ responses to allelic-altered peptide ligands of MSP1 may underlie the evolution of MSP1 dimorphism.

In conclusion, frequently recognized T-cell epitopes have been identified distributed throughout the $P$. falciparum MSP1 with no immunodominant region. IFN- $\gamma$ and IL-4 production were independently regulated and IFN- $\gamma$ allelic Tcell reactivity patterns were discordant with epidemiological parasite allelic prevalence for specific MSP1 epitopes. These results suggest that MSP1 dimorphism may have evolved to evade Th1 T-cell responses. Further understanding of the immunological-selection pressure(s) that maintain MSP1 dimorphism will be required before deployment of candidate MSP1 vaccines in the field.

Acknowledgments: We thank Hilton Whittle, Keith McAdam, the Gambian, Kenyan and Oxford blood donors, Momodou Sanyang, Bolong Jaiteh, and Hassan Joof for assistance.

Financial support: This study was supported by the Wellcome Trust. Edwin A.M. Lee is a Wellcome Trust Prize Student, Katie L. Flanagan is a Wellcome Trust Training Fellow in Clinical Tropical Medicine, Kevin Marsh is a Wellcome Trust Senior Fellow in Clinica Sciences, and Adrian V.S. Hill is a Wellcome Trust Principal Research Fellow.

Authors' addresses: Edwin A.M. Lee, Katie L. Flanagan, William H.H. Reece, Colin Potter, Adrian V.S. Hill, and Magdalena Plebanski, Molecular Immunology Group, Institute of Molecular Medicine, 
Nuffield Department of Medicine, University of Oxford, John Radcliffe Hospital, Oxford, OX3 9DU, United Kingdom. Kennedy Odhiambo and Kevin Marsh, Kenya Medical Research Institute, Kilifi Research Unit, PO Box 428, Kilifi, Kenya. Robin Bailey, London School of Hygiene and Tropical Medicine, Keppel Street, London, WC1E 7HT, United Kingdom. Margaret Pinder, Medical Research Council Laboratories, Fajara PO Box 273, Banjul, The Gambia. The current address of Magdalena Plebanski is Vaccine Development and Infectious Diseases Unit, The Austin Research Institute, Studley Road, Victoria 3084, Australia.

Reprint requests: Edwin A. M. Lee, Molecular Immunology Group, Institute of Molecular Medicine, Nuffield Department of Medicine, University of Oxford, John Radcliffe Hospital, Oxford, OX3 9DU, United Kingdom. Telephone: 441865 222301; Fax: 441865221921 (e-mail: elee@molbiol.ox.ac.uk).

\section{REFERENCES}

1. Good MF, Kaslow DC, Miller LH, 1998. Pathways and strategies for developing a malaria blood-stage vaccine. Ann. Rev. Immunol. 16: 57-87.

2. Miller LH, Hoffman SL, 1998. Research toward vaccines against malaria. Nat Med 4: 520-524.

3. Daly TM, Long CA, 1995. Humoral response to a carboxylterminal region of the merozoite surface protein-1 plays a predominant role in controlling blood-stage infection in rodent malaria. J Immunol 155: 236-243.

4. Ling IT, Ogun SA, Holder AA, 1995. The combined epidermal growth factor-like modules of Plasmodium yoelii Merozoite Surface Protein-1 are required for a protective immune response to the parasite. Parasite Immunol 17: 425-433.

5. Chang SP, Case SE, Gosnell WL, Hashimoto A, Kramer KJ, Tam LQ, Hashiro CQ, Nikaido CM, Gibson HL, Lee Ng CT, Barr PJ, Yokota BT, Hut GS, 1996. A recombinant baculovirus 42-kilodalton $\mathrm{C}$-terminal fragment of Plasmodium falciparum merozoite surface protein 1 protects Aotus monkeys against malaria. Infect Immun 64: 253-261.

6. Etlinger HM, Caspers P, Matile H, Schoenfeld HJ, Stueber D, Takacs B, 1991. Ability of recombinant or native proteins to protect monkeys against heterologous challenge with Plasmodium falciparum. Infect Immun 59: 3498-3503.

7. Egan AF, Morris J, Barnish G, Allen S, Greenwood BM, Kaslow DC, Holder AA, Riley EM, 1996. Clinical immunity to Plasmodium falciparum malaria is associated with serum antibodies to the 19-kDa C-terminal fragment of the merozoite surface antigen, PfMSP-1. J Infect Dis 173: 765-769.

8. Shi YP, Sayed U, Qari SH, Roberts JM, Udhayakumar V, Oloo AJ, Hawley WA, Kaslow DC, Nahlen BL, Lal AA, 1996. Natural immune response to the C-terminal 19-kilodalton domain of Plasmodium falciparum merozoite surface protein 1. Infect Immun 64: 2716-2723.

9. Crisanti A, Muller HM, Hilbich C, Sinigaglia F, Matile H, McKay M, Scaife J, Beyreuther K, Bujard H, 1988. Epitopes recognized by human $\mathrm{T}$ cells map within the conserved part of the GP190 of P. falciparum. Science 240: 1324-1326.

10. Crisanti A, Fruh K, Muller HM, Bujard H, 1990. The T-cell reactivity against the major merozoite protein of Plasmodium falciparum. Immunol Lett 25: 143-148.

11. Egan A, Waterfall M, Pinder M, Holder A, Riley E, 1997. Characterization of human $\mathrm{T}$ - and B-cell epitopes in the $\mathrm{C}$ terminus of Plasmodium falciparum merozoite surface protein 1: evidence for poor T-cell recognition of polypeptides with numerous disulfide bonds. Infect Immun 65: 3024-3031.

12. Quakyi IA, Currier J, Fell A, Taylor DW, Roberts T, Houghten RA, England RD, Berzofsky JA, Miller LH, Good MF, 1994. Analysis of human $\mathrm{T}$ cell clones specific for conserved peptide sequences within malaria proteins. Paucity of clones responsive to intact parasites. J Immunol 153: 2082-2092.

13. Simitsek PD, Ramirez E, Perrin LH, 1990. Structural diversity of Plasmodium falciparum gp200 is detected by T cells. Eur J Immunol 20: 1755-1759.

14. Sinigaglia F, Takacs B, Jacot H, Matile H, Pink JR, Crisanti A, Bujard H, 1988. Nonpolymorphic regions of p190, a protein of the Plasmodium falciparum erythrocytic stage, contain both T and B cell epitopes. J Immunol 140: 3568-3572.

15. Udhayakumar V, Anyona D, Kariuki S, Shi YP, Bloland PB, Branch OH, Weiss W, Nahlen BL, Kaslow DC, Lal AA, 1995. Identification of $\mathrm{T}$ and $\mathrm{B}$ cell epitopes recognized by humans in the C-terminal $42-\mathrm{kDa}$ domain of the Plasmodium falciparum merozoite surface protein (MSP)-1. J Immunol 154: 6022-6030.

16. Riley EM, Allen SJ, Wheeler JG, Blackman MJ, Bennett S, Takacs B, Schonfeld HJ, Holder AA, Greenwood BM, 1992. Naturally acquired cellular and humoral immune responses to the major merozoite surface antigen (PfMSP1) of Plasmodium falciparum are associated with reduced malaria morbidity. Parasite Immunol 14: 321-337.

17. Riley EM, Morris Jones S, Blackman MJ, Greenwood BM, Holder AA, 1993. A longitudinal study of naturally acquired cellular and humoral immune responses to a merozoite surface protein (MSP1) of Plasmodium falciparum in an area of seasonal malaria transmission. Parasite Immunol 15: 513-524.

18. Stevenson MM, Tam MF, 1993. Differential induction of helper T cell subsets during blood-stage Plasmodium chabaudi AS infection in resistant and susceptible mice. Clin Exp Immunol 92: 77-83.

19. Taylor Robinson AW, Phillips RS, 1993. Protective CD4+ Tcell lines raised against Plasmodium chabaudi show characteristics of either Th1 or Th2 cells. Parasite Immunol 15: 301-310.

20. Taylor Robinson AW, Phillips RS, 1994. B cells are required for the switch from Th1- to Th2-regulated immune responses to Plasmodium chabaudi chabaudi infection. Infect Immun 62: 2490-2498.

21. Shirai A, Holmes K, Klinman D, 1993. Detection and quantitation of cells secreting IL-6 under physiologic conditions in BALB/c mice. J Immunol 150: 793-799.

22. King CL, Nutman TB, 1993. IgE and IgG subclass regulation by IL-4 and IFN-gamma in human helminth infections. Assessment by B cell precursor frequencies. J Immunol 151: 458-465.

23. Tanabe K, Mackay M, Goman M, Scaife JG, 1987. Allelic dimorphism in a surface antigen gene of the malaria parasite Plasmodium falciparum. J Mol Biol 195: 273-287.

24. Conway DJ, Greenwood BM, McBride JS, 1992. Longitudinal study of Plasmodium falciparum polymorphic antigens in a malaria-endemic population. Infect Immun 60: 1122-1127.

25. Babiker HA, Creasey AM, Fenton B, Bayoumi RA, Arnot DE, Walliker D, 1991. Genetic diversity of Plasmodium falciparum in a village in eastern Sudan. 1. Diversity of enzymes, 2D-PAGE proteins and antigens. Trans $R$ Soc Trop Med Hyg 85: 572-577.

26. Greenwood BM, Bradley AK, Greenwood AM, Byass P, Jammeh K, Marsh K, Tulloch S, Oldfield FS, Hayes R, 1987. Mortality and morbidity from malaria among children in a rural area of The Gambia, West Africa. Trans $R$ Soc Trop Med Hyg 81: 478-486.

27. Trape JF, Lefebvre Zante E, Legros F, Ndiaye G, Bouganali H, Druilhe P, Salem G, 1992. Vector density gradients and the epidemiology of urban malaria in Dakar, Senegal. Am J Trop Med Hyg 47: 181-189.

28. Davenport MP, Quinn CL, Chicz RM, Green BN, Willis AC, Lane WS, Bell JI, Hill AVS, 1995. Naturally processed peptides from two disease-resistance-associated HLA-DR13 alleles show related sequence motifs and the effects of the dimorphism at position 86 of the HLA-DR beta chain. Proc Natl Acad Sci U S A 92: 6567-6571.

29. Hill AV, Allsopp CE, Kwiatkowski D, Anstey NM, Twumasi P, Rowe PA, Bennett S, Brewster D, McMichael AJ, Greenwood BM, 1991. Common West African HLA antigens are associated with protection from severe malaria. Nature 352: 595600 .

30. Davenport MP, Ho Shon IA, Hill AVS, 1995. An empirical method for the prediction of T-cell epitopes. Immunogenetics 42: 392-397.

31. Sokal RR, Rohlf JF, eds., 1995. Biometry: The Principles and 
Practice of Statistics in Biological Research. New York: WH Freeman, 68-70.

32. Gilbert SC, Plebanski M, Gupta S, Morris J, Cox M, Aidoo M, Kwiatkowski D, Greenwood BM, Whittle HC, Hill AV, 1998. Association of malaria parasite population structure, HLA, and immunological antagonism. Science 279: 1173-1177.

33. Egan AF, Chappel JA, Burghaus PA, Morris JS, McBride JS, Holder AA, Kaslow DC, Riley EM, 1995. Serum antibodies from malaria-exposed people recognize conserved epitopes formed by the two epidermal growth factor motifs of MSP1(19), the carboxy-terminal fragment of the major merozoite surface protein of Plasmodium falciparum. Infect Immun 63: 456-466.

34. Deloron P, Chougnet C, Lepers JP, Tallet S, Coulanges P, 1991. Protective value of elevated levels of gamma interferon in serum against exoerythrocytic stages of Plasmodium falciparum. J Clin Microbiol 29: 1757-1760.

35. Kumaratilake LM, Ferrante A, 1994. T-cell cytokines in malaria: their role in the regulation of neutrophil- and macrophagemediated killing of Plasmodium falciparum asexual blood forms. Res Immunol 145: 423-429.

36. Stevenson MM, Ghadirian E, Phillips NC, Rae D, Podoba JE, 1989. Role of mononuclear phagocytes in elimination of Plasmodium chabaudi AS infection. Parasite Immunol 11: 529544.

37. Ockenhouse CF, Schulman S, Shear HL, 1984. Induction of crisis forms in the human malaria parasite Plasmodium falciparum by gamma-interferon-activated, monocyte-derived macrophages. J Immunol 133: 1601-1608.

38. Nussler A, Drapier JC, Renia L, Pied S, Miltgen F, Gentilini M, Mazier D, 1991. L-arginine-dependent destruction of intrahepatic malaria parasites in response to tumor necrosis factor and/or interleukin 6 stimulation. Eur J Immunol 21: 227-230.

39. Stevenson MM, Tam MF, Wolf SF, Sher A, 1995. IL-12-induced protection against blood-stage Plasmodium chabaudi AS requires IFN-gamma and TNF-alpha and occurs via a nitric oxide-dependent mechanism. J Immunol 155: 2545-2556.

40. Bouharoun Tayoun H, Attanath P, Sabchareon A, Chongsuphajaisiddhi T, Druilhe P, 1990. Antibodies that protect humans against Plasmodium falciparum blood stages do not on their own inhibit parasite growth and invasion in vitro, but act in cooperation with monocytes. J Exp Med 172: 1633-1641.

41. Clark IA, Ilschner S, MacMicking JD, Cowden WB, 1990. TNF and Plasmodium berghei ANKA-induced cerebral malaria. Immunol Lett 25: 195-198.

42. Maheshwari RK, Czarniecki CW, Dutta GP, Puri SK, Dhawan
BN, Friedman RM, 1986. Recombinant human gamma interferon inhibits simian malaria. Infect Immun 53: 628-630.

43. Ferrante A, Kumaratilake L, Rzepczyk CM, Dayer JM, 1990 Killing of Plasmodium falciparum by cytokine activated ef fector cells (neutrophils and macrophages). Immunol Lett 25: 179-187.

44. Druilhe P, Sabchareon A, Bouharoun-Tayoun H, Oeuvray C, Perignon JL, 1997. In vivo veritas: lessons from immunoglobulin-transfer experiments in malaria patients. Ann. Tro. Med Parasitol 91: S37-S53.

45. Bouharoun Tayoun H, Oeuvray C, Lunel F, Druilhe P, 1995 Mechanisms underlying the monocyte-mediated antibody-dependent killing of Plasmodium falciparum asexual blood stages. J Exp Med 182: 409-418.

46. Luty AJ, Lell B, Schmidt Ott R, Lehman LG, Luckner D, Greve B, Matousek P, Herbich K, Schmid D, Migot Nabias F, Deloron P, Nussenzweig RS, Kremsner PG, 1999. Interferongamma responses are associated with resistance to reinfection with Plasmodium falciparum in young African children. $J$ Infect Dis 179: 980-988.

47. Good MF, Pombo D, Quakyi IA, Riley EM, Houghten RA, Menon A, Alling DW, Berzofsky JA, Miller LH, 1988. Human T-cell recognition of the circumsporozoite protein of Plasmodium falciparum: immunodominant T-cell domains map to the polymorphic regions of the molecule. Proc Natl Acad Sci U S A 85: 1199-1203.

48. Hughes AL, 1992. Positive selection and interallelic recombination at the merozoite surface antigen-1 (MSA-1) locus of Plasmodium falciparum. Mol Biol Evol 9: 381-393.

49. Hughes MK, Hughes AL, 1995. Natural selection on Plasmodium surface proteins. Mol Biochem Parasitol 71: 99-113.

50. Plebanski M, Lee EA, Hannan CM, Flanagan KL, Gilbert SC, Gravenor MB, Hill AV, 1999. Altered peptide ligands narrow the repertoire of cellular immune responses by interfering with T-cell priming. Nat Med 5: 565-571.

51. Plebanski M, Lee EA, Hill AV, 1997. Immune evasion in malaria: altered peptide ligands of the circumsporozoite protein. Parasitology 115 Suppl: S55-66.

52. Holder AA, Blackman MJ, 1994. What is the function of MSP1 on the malaria merozoite? Parasitol. Today 10: 182-184.

53. Ho M, Webster HK, 1989. Immunology of human malaria. A cellular perspective. Parasite Immunol 11: 105-116.

54. Conway DJ, 1997. Natural selection on polymorphic malaria antigens and the search for a vaccine. Parasitol Today 13: 26-29.

55. Miller LH, Roberts T, Shahabuddin M, McCutchan TF, 1993 Analysis of sequence diversity in the Plasmodium falciparum merozoite surface protein-1 (MSP-1). Mol Biochem Parasitol 59: $1-14$. 